(C) 2016. This manuscript version is made available under the CC-BY-NC-ND 4.0 license http://creativecommons.org/licenses/by-nc-nd/4.0/

Study of modified atmosphere packaging on the quality of ozonated freeze-dried chicken meat

Ferdaous Zouaghi, María J. Cantalejo

Meat Science, Volume 119, September 2016, Pages 123-131

DOI: http://doi.org/10.1016/j.meatsci.2016.04.032 


\section{Study of modified atmosphere packaging on the quality of ozonated freeze-dried chicken meat}

\section{Introduction}

Poultry meats are widely consumed freshly in Europe, but in fact they are highly perishable to bacterial contaminants due to their composition, a high water activity $\left(a_{w}\right)$, and a high final $\mathrm{pH}$, limiting the shelf-life of the products. Spoilage of fresh poultry products is an economic burden to the producer (Petrou, Tsiraki, Giatrakou, \& Savvaidis, 2012); so, developing effective hurdle technologies to extend the shelf-life and to keep the product quality during long periods represents a major task for the poultry processing industry. According to Cantalejo et al.(2016), the combined effect of gaseous ozone and lyophilisation in chicken breast meat showed great antimicrobial effectiveness, due to the action of ozone, as well as the low percentage of humidity $(<10 \%)$ and water activity below 0.5 of the product. These techniques also allowed extending the shelf-life of those products during 8 months of storage at room temperature without refrigeration.

However, the combination of those hurdles were not sufficient to maintain the physicochemical (texture) and sensory qualities of the ozonated dried meat for long time (Zouaghi, 2011). In fact, the loss of textural qualities (i.e., tenderness and juiciness) was the main problem in freeze-dried meats, maybe due to denaturizing of proteins, followed by their aggregation (Babić, Cantalejo, \& Arroqui, 2009). Hence, as a result of an increasing demand for healthy and high-quality products, a need emerged for further research work involving the possibility of maintaining better sensory quality of ozonated freeze-dried chicken meat to reach more potential markets and satisfy consumer demands, hardness and juiciness being some of the main criteria influencing consumer’s acceptability (Ganhão, Morcuende, \& Estévez, 2010). According to Babić et al. (2009), the freeze-dried meat products which have been adequately packaged can be stored for unlimited periods retaining the majority of their physical, chemical, biological and sensory properties as in the fresh state.

In this context, modified atmosphere packaging (MAP) has been considered in this study as a useful technique to maintain the sensory quality and to extend the shelf-life of several foods commodities, including chicken meat (Chouliara, Karatapanis, Savvaidis, 
\& Kontominas, 2007). García-Esteban et al., (2004) stated that modified atmosphere packaging preserved meat (i.e. dry-cured ham) from hardening and deterioration of textural properties more efficiently than vacuum packaging. The principle of MAP is the replacement of the atmosphere surrounding a product before sealing, carbon dioxide, oxygen and nitrogen, being the most commonly used gases. Carbon dioxide possesses bacteriostatic activity (Nair, Kiess, Nannapaneni, Schilling, \& Sharma, 2015). Oxygen is important to retain meat color and nitrogen results essential to avoid oxidation of fats and pack collapse. These gases can be applied individually or in combination, in order to achieve an optimum effect, depending on the specific needs of the particular food products being preserved (Narasimha Rao \& Sachindra, 2002). Therefore, the aim of this study was to evaluate the effects of MAP conditions on the physicochemical and sensory properties of ozonated freeze-dried chicken meat stored at room temperature, in order to develop new high-quality raw meat products from fresh chicken meat, safe, with a high nutritional value, with no additives added and stable over time at room temperature. Also, the new raw products from fresh poultry meat represent an alternative, as they would allow a length in the retail period in the case of natural catastrophes, military campaigns, export to third countries, scarcity in electricity supply, etc. This is the first time that these three combined techniques (ozonation, freeze-drying and MAP) have been applied on poultry meats.

\section{Materials and methods}

\subsection{Samples preparation}

Broiler chicken breast meat was provided by U.V.E., S.A. Company (Tudela, Navarre, Spain). Chickens were 42 days old before slaughtering with approximately 2 $\mathrm{kg}$ of weight. All breasts were stored in a refrigerated room $\left(2-4{ }^{\circ} \mathrm{C}\right)$ for the time of reception until used. The initial load of total aerobic mesophilic bacteria (TAMB) (b5 log cfu/g), lactic acid bacteria (LAB) ( $<4 \log \mathrm{cfu} / \mathrm{g})$, Escherichia coli $(<2 \log \mathrm{cfu} / \mathrm{g})$ and Salmonella spp. (not detected in any of the chicken samples) was determined before samples were processed. The samples were trimmed of visible fat and nerves; they were cut into pieces (approximately $3 \times 3 \mathrm{~cm}^{2}$ of section and of $0.7 \mathrm{~cm}$ in thickness). Then, they were divided into two trials: the first trial was vacuum packaging, deep frozen and stored at $-40 \pm 1{ }^{\circ} \mathrm{C}$ (Climas, Barcelona, Spain) and used as an external control of raw meat (untreated samples) for physical-chemical measurements $(\mathrm{pH}$, color, and texture) 
and sensory analyses and to characterize the raw material. The second trial was subjected to a combined treatment of gaseous ozone, freeze-drying and modified atmosphere packaging (MAP) as described below.

\subsection{Ozone treatments}

After having prepared the breast samples, they were treated first with ozone. Ozonation assays were carried out in a $3 \mathrm{~m}^{3}$ volume refrigerated chamber (Eurozon, Ecologyc 2000, Sestao, Vizcaya, Spain) to a continuous flow of ozone gas at $4 \pm 0.5^{\circ} \mathrm{C}$ and $90 \pm 1 \%$ relative humidity. These conditions are important for the efficiency of the bactericidal effect of ozone (Kim, Yousef, \& Chism, 1999). Ozone in form of gas was generated in situ utilizing a UV radiation using an ozone generator (Rilize, model 3060, Eurozon, Sestao, Spain). Ozone concentrations inside the chamber were monitored continuously by circulating air from the chamber through an ultraviolet absorption ozone gas analyzer (Ozomat MP, Anseros, Germany). The conditions of ozonation were described by Zouaghi (2011) for Broiler chicken meat and were the same in all treatments, where the samples were exposed to gaseous ozone for 10 minutes with a dose of $0.6 \mathrm{ppm}$ to reduce the initial levels of contamination (a reduction about $1.1 \mathrm{log}$ cfu/g was observed in TAMB, LAB and E. coli, Salmonella spp. was not detected in any of the chicken samples).

\subsection{Freeze-drying process}

After ozone treatments, samples were dehydrated in a pilot scale freeze-dryer (Model Lyobeta 25, Telstar Industrial, S.L., Barcelona, Spain). The different parameters of the freeze-drying process assayed in this study were the same in all treatments and were the best conditionsdesibed in the resarb work of Babic et al. (2009). The initial $\mathrm{a}_{\mathrm{w}}$ and moisture content of fresh chicken meat were about $0.984 \pm 0.002$ and $73.88 \pm 0.06 \%$, respectively. After lyophilisation, a significant decrease $(P<0.05)$ in those values was observed for the samples treated with lyophilisation $(0.131 \pm 0.002$ for $\mathrm{a}_{\mathrm{w}}$ and $2.93 \pm 0.06 \%$ for humidity).

\subsection{Packaging}

After ozone and freeze-drying treatment, all samples were individually packaged in low-O2-permeable polystyrene/ ethylvinylalcohol $(\mathrm{EVOH}) /$ polyethylene $(\mathrm{PE})$ trays and heat-sealed using a low O2-permeable cling film consisting of polyethylene terephthalate (PET)/ EVOH/ Polypropylene (PP) on the inside of the outer layer as a gas barrier, supplied by Ilpra Systems, S.L. (Barcelona, Spain). The trays had an oxygen 
transfer rate of less than $50 \mathrm{~cm}^{3} \mathrm{~m}^{-2} \mathrm{~d}^{-1}$ bar $^{-1}$, permeability to $\mathrm{CO}_{2}$ less than $150 \mathrm{~cm}^{3} \mathrm{~m}^{-2}$ $\mathrm{d}^{-1}$ bar $^{-1}$ and a water vapour permeability of less than $2.8 \mathrm{~g} \mathrm{~m}^{-2} \mathrm{~d}^{-1}$. Samples were packaged using a packaging machine (Ilpra Termosaldatrici, España) with a sample/gas ratio of 1:3 (w/v). The untreated samples (frozen meat) were vacuum packed in impermeable plastic trays (type PA/ PE 20/70 200 x 300) using a vacuum packaging machine (Model SAMMIC V-640, Gipuzkoa, Spain).

\subsection{Modified atmosphere packaging experiments}

In the present study, three different trials were carried out to evaluate the effect of modified packaging on the physicochemical and the sensory changes of ozonated dried chicken meat stored at different packaging atmosphere conditions, in order to choose the most suitable packaging conditions. The modified atmosphere gas conditions assayed are listed in Table 5.1.

Table 1. Experiments and different conditions used for ozonated freeze-dried chicken meat in modified atmosphere packaging.

\begin{tabular}{|c|c|c|c|c|}
\hline \multirow[t]{2}{*}{ Trials } & \multirow[t]{2}{*}{ Experiments } & \multicolumn{3}{|c|}{ Packaging conditions } \\
\hline & & $\mathrm{O}_{2}(\%)$ & $\mathrm{CO}_{2}(\%)$ & $\mathrm{N}_{2}(\%)$ \\
\hline \multirow[t]{3}{*}{ Trial i } & 1 & 20 & - & 80 \\
\hline & 2 & 30 & - & 70 \\
\hline & 3 & 0 & - & 100 \\
\hline \multirow[t]{4}{*}{ Trial ii } & 1 & - & 20 & 80 \\
\hline & 2 & - & 30 & 70 \\
\hline & 3 & - & 40 & 60 \\
\hline & 4 & - & 50 & 50 \\
\hline \multirow[t]{7}{*}{ Trial iii } & 1 & 10 & 30 & 60 \\
\hline & 2 & 20 & 30 & 50 \\
\hline & 3 & 30 & 30 & 40 \\
\hline & 4 & 20 & 20 & 60 \\
\hline & 5 & 30 & 20 & 50 \\
\hline & 6 & 40 & 20 & 40 \\
\hline & 7 & 20 & 10 & 70 \\
\hline
\end{tabular}

The first set of trials (i) consisted of three experiments in which meat was packaged with three different oxygen concentrations $\left(0,20\right.$ and $\left.30 \% \mathrm{O}_{2}\right)$. This trial was planned in order to examine the influence of the effect of $\mathrm{O}_{2}$ levels on the quality of MAP ozonated dried chicken. In the second trial (ii), the samples were packaged with four levels of $\mathrm{CO}_{2}\left(20,30,40\right.$ and $\left.50 \% \mathrm{CO}_{2}\right)$, in order to evaluate the effect of carbon dioxide 
concentration on the quality of MAP ozonated dried chicken. Based on the results of trail (i) and trial (ii), the third trial (iii) was designed by using seven different compositions of $\mathrm{O}_{2} / \mathrm{CO}_{2} / \mathrm{N}_{2}$ mixture. The concentrations of $\mathrm{O}_{2}, \mathrm{CO}_{2}$ and $\mathrm{N}_{2}$ varied from one treatment to another, in order to determine the best $\mathrm{O}_{2}: \mathrm{CO}_{2}$ ratio needed to maintain the quality of ozonated freeze-dried chicken meat during 28 days of storage.

\subsection{Storage conditions}

After packaging, samples were coded and stored in a dark place at room temperature $\left(21 \pm 1{ }^{\circ} \mathrm{C}\right)$ for 28 days. The untreated samples (frozen meat) were kept at $-40{ }^{\circ} \mathrm{C}$ until analyses. All samples were analysed on days 1, 7, 15, 21 and 28 for physicochemical and sensory analyses. The 28 day period was the time allotted in order to verify the effectiveness of each MAP treatment where the degree of possible changes in hardness and juiciness was measured, because in preliminary studies they were the most affected by freeze-drying. A comparative study of those parameters of both the original fresh chicken meat and the treated meat was undergone.

\subsection{Physicochemical analyses}

\section{Headspace gas composition}

The concentrations of $\mathrm{O}_{2}, \mathrm{CO}_{2}$ and $\mathrm{N}_{2}$ inside the trays (three from each experiment) were measured using a gas analyser (Gas-space Systech Instruments, S.A, Madrid, Spain) every day before meat analyses Gas analyses were performed by piercing a syringe needle through a rubber septum glued on the surface of the plastic film. Three measurements were carried out for each tray.

\section{pH, color and texture profile analyses (TPA)}

The $\mathrm{pH}$ was measured using a pH meter (Crison PH 25, S.A, Barcelona, Spain) with a combined electrode which penetrated the meat samples. The $\mathrm{pH}$ meter was calibrated with $\mathrm{pH} 4$ and $\mathrm{pH} 7$ standard solutions.Color measurements were performed using a Minolta Chrome Meter CM-2500d (Minolta Co. Ltd. Osaka, Japan), with specular reflectance excluded, $8 \mathrm{~mm}$ diameter measuring aperture and D65 illuminator at $10^{\circ}$ standard observer angle. Color coordinates obtained in the CIELAB space with specular component included $\mathrm{L}^{*}$ (lightness), $\mathrm{a}^{*}$ (redness) and $\mathrm{b}^{*}$ (yellowness). The total difference for two color measurements is given by the following formula (Chouhan, Pal, \& Rao, 2015): $\Delta E_{a b}^{*}=\sqrt{\left(\Delta L^{*}\right)^{2}+\left(\Delta a^{*}\right)^{2}+\left(\Delta b^{*}\right)^{2}}$ where $\Delta \mathrm{L}^{*}, \Delta \mathrm{a}^{*}$ an $\Delta \mathrm{b}^{*}$ are the difference in the $\mathrm{L}^{*}, \mathrm{a}^{*}$, and $\mathrm{b}^{*}$ measured at day 28 of storage and their values at day 0 . 
Texture profile analyses (TPA) were performed with a TA.XT Plus Texture Analyser (Stable Micro Systems Ltd, Aname S.L, England). Ten samples from each experiment were taken parallel to the longitudinal orientation of the muscular fibres. Prior to the analyses, samples were packaged in impermeable plastic bags and cooked in a water bath at $80{ }^{\circ} \mathrm{C}$ for $2 \mathrm{~min}$. The samples were compressed perpendicularly to muscle fibre orientation to $70 \%$ original height through a two consecutive cycles, with $3 \mathrm{~s}$ between cycles, using a cylindrical probe of $12.8 \mathrm{~mm}$ diameter. The crosshead moved at a constant speed of $2 \mathrm{~mm} / \mathrm{s}$. The following texture profile parameters were determined as described by Bourne (1978) and Szczesniak (1995): hardness (N) maximum force required to compress the sample, cohesiveness (dimensionless), extent to which the sample could be deformed before it ruptures, and chewiness $(\mathrm{N} / \mathrm{mm})$, calculated as the product of hardness, springiness and cohesiveness (Meral \& Mahmut, 2016; Savadkoohi, Hoogenkamp, Shamsi, \& Farahnaky, 2014).

Treated samples had to be rehydrated and cooked in order to be analyzed. The duration of rehydration process was fixed in $3 \mathrm{~h}$, as after that time period there was no more absorption of water by the samples (Babić et al., 2009)

\subsection{Sensory descriptive analyses}

The descriptive sensory evaluation was performed by 6 trained panelists in two sessions: the first one, to visually evaluate the attributes of the rehydrated chicken meat, and the second one to evaluate all the texture profile attributes of the rehydrated-cooked treated chicken meat. Each sample was served in white plates and shown with three random numbers. The method of Hunt et al. (1991) was adapted to describe the sensory characteristics of the rehydrated treated chicken meat in five attributes: appearance, percentage of surface discoloration, chicken odour, odour characteristics and overall impression. For the evaluation of the texture profile attributes, the panel evaluated the rehydrated-cooked treated chicken meat (3 cube-shaped samples per panelist) for the three following sensory attributes: hardness, juiciness and chewiness (Lyon \& Lyon, 1990). Each attribute was rated on a seven-point scale, with score 1 equivalent to the lowest score and 7 indicates the highest score. In both evaluations, visual and textural, the limit of acceptability was 4 . 


\subsection{Statistical analyses}

An analysis of variance (ANOVA) using the General Linear Model (GLM) procedure of the SPSS package (SPSS 21, Chicago, IL, USA) was performed, in which the measured variables were set as dependent variables, treatments and storage time were assigned as fixed effects and replicates were assigned as random effects. The pairwise differences between least-squae meanswere evaluated by Tukey'sHSD test. Differences were considered significant when $P<0.05$. The values were given in terms of mean values and standard errors in tables and figures. Correlations among variables were determined by correlation analyses using Pearson's linear correlation coefficient with the above-mentioned software package.

\section{Results and discussion}

\subsection{Trial $i$. Packaging under different oxygen concentrations (0, 20 and $30 \%)$}

\section{Headspace composition}

A small but statistically significant $(P<0.05)$ change in gas composition of each package was recorded from day 15 onwards (data not shown). In fact, the $\mathrm{O}_{2}$ concentration inside the trays showed a small decrease in both atmospheres $\left(0 \% \mathrm{O}_{2} / 100\right.$ $\% \mathrm{~N}_{2}$ and $30 \% \mathrm{O}_{2} / 70 \% \mathrm{~N}_{2}$ ) from initial values of $0.57 \pm 0.01 \%$ and $29.41 \pm 0.03 \%$ to final values of $0.50 \pm 0.00 \%$ and $28.25 \pm 0.03 \%$ respectively. This was caused by meat enzyme respiration (Rossaint, Klausmann, \& Kreyenschmidt, 2014).

\section{pH and color change}

The evolution of $\mathrm{pH}$ and color parameters values ( $\mathrm{L}^{*}, \mathrm{a}^{*}$ and $\left.\mathrm{b}^{*}\right)$ during storage in different packs is summarized in Table 5.2. The $\mathrm{pH}$ values for frozen meat varied between $5.66 \pm 0.04$ and $5.92 \pm 0.02$, whereas those of treated samples ranged between $5.67 \pm 0.03$ and $6.02 \pm 0.04$. These values of $\mathrm{pH}$ were lower than those reported by Cantalejo et al. (2016) in chicken meat treated with ozone and lyophilisation. However, the $\mathrm{pH}$ values generally increased with time in all samples with significant differences $(P<0.05)$ on day 28 in samples under $20 \% \mathrm{O}_{2} / 80 \% \mathrm{~N}_{2}$ packaging conditions (and on day 15 under MAP with $30 \% \mathrm{O}_{2} / 70 \% \mathrm{~N}_{2}$ ). Samples packaged under high $\mathrm{O}_{2}$ MAP conditions $\left(30 \% \mathrm{O}_{2} / 70 \% \mathrm{~N}_{2}\right)$ showed the highest $(P<0.05) \mathrm{pH}$ values from day 15 onwards with respect to that of the others treatments. Fernández-López et al. (2008) also 
observed differences in $\mathrm{pH}$ values due to storage time and conditions, in ostrich steaks of initial pH 6.04.

Regarding color parameters, meat stored under MAP with $30 \% \mathrm{O}_{2} / 70 \% \mathrm{~N}_{2}$ showed significant change in $\mathrm{L}^{*}$ value and developed a darker appearance till 28 days. Both gas composition and storage period had a significant effect on the $a^{*}$ values (redness) of chicken meat samples $(P<0.05)$. In the first day of storage, significant differences were observed among samples, the lowest $\mathrm{a}^{*}$ values being obtained in samples packed in 0 $\% \mathrm{O}_{2} / 100 \% \mathrm{~N}_{2}$. From day 15 , the redness value increased slightly $(P<0.05)$ in $0 \% \mathrm{O}_{2} /$ $100 \% \mathrm{~N}_{2}$ packs and decreased significantly $(P<0.05)$ for $\mathrm{O}_{2}$ packaged meat samples up to 28 days. Several authors reported decreases of redness for high $\mathrm{O}_{2}$ packaged chicken (Keokamnerd, Acton, Han, \& Dawson, 2008) and ostrich meat (Fernández-López et al., 2008; Seydim, Acton, Hall, \& Dawson, 2006) during refrigerated storage. The same authors indicated this loss of redness due to oxidation of myoglobin to metmyoglobin in packaged meat. The parameter $b^{*}$ values related to yellowness changed significantly $(P<0.05)$ over time and among the packaging conditions. In $\mathrm{N}_{2}$ packs, $\mathrm{b}^{*}$ value increased progressively during storage, while, in $\mathrm{O}_{2}$ MAP conditions, $\mathrm{b}^{*}$ values decreased $(P<0.05)$ from day 15 onwards. Esmer et al. (2011) stated the loss of redness in meat and the alteration of its color to brownish red by formation of metmyoglobin that leads to the decrease in the $\mathrm{b}^{*}$ value. Further statistical analyses of $\Delta \mathrm{E}^{*}$ values showed that the samples packed in $\mathrm{O}_{2}$ MAP conditions reflected the large color change ( $\Delta \mathrm{E}$ values of 3.7 and 4.4 for $20 \% \mathrm{O}_{2}$ and $30 \% \mathrm{O}_{2}$, respectively) during storage comparted to $0 \% \mathrm{O}_{2} / 100 \% \mathrm{~N}_{2}$ packs $(\Delta \mathrm{E}=1.1)$. 
Table 2. Changes in $\mathrm{pH}, \mathrm{L}^{*}, \mathrm{a}^{*}$ and $\mathrm{b}^{*}$ values of chicken breast meat stored under different MAP $\left(0 \% \mathrm{O}_{2} / 100 \% \mathrm{~N}_{2}, 20 \% \mathrm{O}_{2} / 80 \% \mathrm{~N}_{2}\right.$ and $\left.30 \% \mathrm{O}_{2} / 70 \% \mathrm{~N}_{2}\right)$ during 28 days of storage at room temperature.

\begin{tabular}{cccccc}
\hline Parameters & $\begin{array}{c}\text { Days of } \\
\text { storage }\end{array}$ & \multicolumn{4}{c}{ Treatments } \\
\hline $\mathrm{pH}$ & & Frozen meat $(\mathrm{FM})$ & $0 \% \mathrm{O}_{2} / 100 \% \mathrm{~N}_{2}$ & $20 \% \mathrm{O}_{2} / 80 \% \mathrm{~N}_{2}$ & $30 \% \mathrm{O}_{2} / 70 \% \mathrm{~N}_{2}$ \\
\cline { 3 - 6 } & 1 & $5.80 \pm 0.02$ & $5.71 \pm 0.04^{\mathrm{Aa}}$ & $5.62 \pm 0.04^{\mathrm{Aa}}$ & $5.73 \pm 0.02^{\mathrm{Aa}}$ \\
& 7 & $5.92 \pm 0.02$ & $5.74 \pm 0.02^{\mathrm{Aa}}$ & $5.67 \pm 0.03^{\mathrm{Aa}}$ & $5.77 \pm 0.03^{\mathrm{Aa}}$ \\
& 15 & $5.89 \pm 0.02$ & $5.70 \pm 0.02^{\mathrm{Aa}}$ & $5.69 \pm 0.03^{\mathrm{Aab}}$ & $5.95 \pm 0.03^{\mathrm{Bb}}$ \\
& 21 & $5.75 \pm 0.01$ & $5.68 \pm 0.03^{\mathrm{Aa}}$ & $5.70 \pm 0.02^{\mathrm{Aab}}$ & $5.97 \pm 0.03^{\mathrm{Bb}}$ \\
$\mathrm{L}^{*}$ & 28 & $5.66 \pm 0.04$ & $5.73 \pm 0.04^{\mathrm{Aa}}$ & $5.80 \pm 0.03^{\mathrm{Ab}}$ & $6.02 \pm 0.04^{\mathrm{Bb}}$ \\
& 1 & $43.84 \pm 0.34$ & $66,37 \pm 1.13^{\mathrm{Aa}}$ & $64.23 \pm 0.53^{\mathrm{Aa}}$ & $64.02 \pm 0.77^{\mathrm{Aa}}$ \\
& 7 & $49.83 \pm 0.59$ & $65,53 \pm 0.87^{\mathrm{Aa}}$ & $65.27 \pm 0.85^{\mathrm{Aa}}$ & $64.46 \pm 0.83^{\mathrm{Aab}}$ \\
& 15 & $44.76 \pm 0.27$ & $65,67 \pm 1.12^{\mathrm{Aa}}$ & $65.88 \pm 0.32^{\mathrm{Aa}}$ & $67.36 \pm 0.59^{\mathrm{Ab}}$ \\
& 21 & $43.97 \pm 0.37$ & $63,69 \pm 0.81^{\mathrm{Aa}}$ & $65.24 \pm 0.81^{\mathrm{Aa}}$ & $63.75 \pm 0.55^{\mathrm{Aa}}$ \\
$\mathrm{a}^{*}$ & 28 & $43.68 \pm 0.50$ & $67.23 \pm 1.13^{\mathrm{Ba}}$ & $66.73 \pm 0.50^{\mathrm{Ba}}$ & $61.48 \pm 0.67^{\mathrm{Aa}}$ \\
& & & & & \\
& 1 & $1.11 \pm 0.00$ & $1.37 \pm 0.01^{\mathrm{Aa}}$ & $2.55 \pm 0.02^{\mathrm{Cd}}$ & $2.38 \pm 0.02^{\mathrm{Bf}}$ \\
& 7 & $1.14 \pm 0.00$ & $1.41 \pm 0.02^{\mathrm{Aa}}$ & $1.62 \pm 0.01^{\mathrm{Bc}}$ & $1.84 \pm 0.02^{\mathrm{Cd}}$ \\
& 15 & $1.05 \pm 0.00$ & $1.60 \pm 0.03^{\mathrm{Ab}}$ & $1.62 \pm 0.03^{\mathrm{Ac}}$ & $1.62 \pm 0.03^{\mathrm{Ac}}$ \\
& 21 & $1.04 \pm 0.00$ & $1.72 \pm 0.03^{\mathrm{Cc}}$ & $1.28 \pm 0.02^{\mathrm{Ab}}$ & $1.50 \pm 0.02^{\mathrm{Bb}}$ \\
$\mathrm{b}^{*}$ & 28 & $1.17 \pm 0.01$ & $1.84 \pm 0.02^{\mathrm{Cd}}$ & $1.19 \pm 0.02^{\mathrm{Aa}}$ & $1.27 \pm 0.02^{\mathrm{Ba}}$ \\
& & & & & \\
& 1 & $8.09 \pm 0.09$ & $13.72 \pm 0.10^{\mathrm{Aa}}$ & $17.42 \pm 0.21^{\mathrm{Bc}}$ & $16.70 \pm 0.21^{\mathrm{Bc}}$ \\
& 7 & $7.89 \pm 0.05$ & $15.13 \pm 0.18^{\mathrm{Abc}}$ & $15.56 \pm 0.20^{\mathrm{Ab}}$ & $17.58 \pm 0.23^{\mathrm{Bd}}$ \\
& 15 & $11.67 \pm 0.05$ & $15.43 \pm 0.12^{\mathrm{Cc}}$ & $14.60 \pm 0.15^{\mathrm{Ba}}$ & $13.42 \pm 0.09^{\mathrm{Aa}}$ \\
& 21 & $10.96 \pm 0.10$ & $17.08 \pm 0.27^{\mathrm{Bd}}$ & $17.35 \pm 0.20^{\mathrm{Bc}}$ & $15.08 \pm 0.19^{\mathrm{Ab}}$ \\
& 28 & $9.51 \pm 0.10$ & $14.26 \pm 0.26^{\mathrm{Bab}}$ & $15.06 \pm 0.21^{\mathrm{Cab}}$ & $13.24 \pm 0.16^{\mathrm{Aa}}$ \\
\hline
\end{tabular}

Data are expressed as means \pm standard error $(\mathrm{n}=10)$. MAP samples were previously ozonated and freeze-dried.

A,B,C Different capital letters in the same raw indicate that means are significantly different $(P<0.05)$ between the different MAP packaging.

a,b,c Different lowercase letters in the same column indicate that means are significantly different $(P<0.05)$ between days of storage

\section{Texture analyses}

Table 5.3 shows the effect of packaging conditions and storage time on texture parameters measured instrumentally. Treated samples showed significantly $(P<0.05)$ higher textural parameters values compared to untreated meat samples (frozen meat). Similar results were reported by Cantalejo et al. (2016) who found that chicken meat treated with ozone and freeze-drying was tougher when compared with the control meat. During storage, increased hardness and chewiness values and reduced cohesiveness values were obtained for all samples.

Hardness and chewiness showed higher values in samples packed under high oxygen concentrations (30\%) throughout the storage time compared to samples packaged under low concentrations of $\mathrm{O}_{2}(0$ and $20 \%)$. The increase of hardness and other related 
texture parameters are highly undesirable, as this could have a great impact on consumer acceptability (Ganhão et al., 2010).

Table 3. TPA parameters of the chicken meat packed with different MAP $\left(0 \% \mathrm{O}_{2} /\right.$ $100 \% \mathrm{~N}_{2}, 20 \% \mathrm{O}_{2} / 80 \% \mathrm{~N}_{2}$ and $30 \% \mathrm{O}_{2} / 70 \% \mathrm{~N}_{2}$ ) during 28 days of storage

\begin{tabular}{lccccc}
\hline Parameters & $\begin{array}{c}\text { Days of } \\
\text { storage }\end{array}$ & $\begin{array}{c}\text { Frozen meat } \\
\text { (FM) }\end{array}$ & & MAP condition & \\
\hline & & & $0 \% \mathrm{O}_{2} / 100 \% \mathrm{~N}_{2}$ & $20 \% \mathrm{O}_{2} / 80 \% \mathrm{~N}_{2}$ & $30 \% \mathrm{O}_{2} / 70 \% \mathrm{~N}_{2}$ \\
\cline { 4 - 6 } Hardness (N) & 1 & $34.32 \pm 0.44$ & $45.66 \pm 0.59^{\mathrm{Ba}}$ & $45.10 \pm 0.33^{\mathrm{Ba}}$ & $39.16 \pm 0.35^{\mathrm{Aa}}$ \\
& 7 & $33.44 \pm 0.35$ & $47.67 \pm 0.52^{\mathrm{Bab}}$ & $51.69 \pm 0.49^{\mathrm{Cb}}$ & $45.49 \pm 0.60^{\mathrm{Ab}}$ \\
& 15 & $31.60 \pm 0.25$ & $49.68 \pm 0.60^{\mathrm{Bb}}$ & $52.08 \pm 0.72^{\mathrm{Cb}}$ & $47.84 \pm 0.31^{\mathrm{Ac}}$ \\
& 21 & $30.78 \pm 0.34$ & $52.74 \pm 0.20^{\mathrm{Bc}}$ & $56.50 \pm 0.42^{\mathrm{Cc}}$ & $49.93 \pm 0.57^{\mathrm{Ad}}$ \\
& 28 & $35.80 \pm 0.09$ & $58.19 \pm 0.96^{\mathrm{Bd}}$ & $58.59 \pm 1.13^{\mathrm{Bc}}$ & $50.55 \pm 0.37^{\mathrm{Ad}}$ \\
& & & & & \\
& 1 & $0.43 \pm 0.01$ & $0.54 \pm 0.00^{\mathrm{Ae}}$ & $0.59 \pm 0.00^{\mathrm{Ce}}$ & $0.58 \pm 0.00^{\mathrm{Be}}$ \\
& 7 & $0.41 \pm 0.01$ & $0.52 \pm 0.00^{\mathrm{Ac}}$ & $0.57 \pm 0.00^{\mathrm{Cd}}$ & $0.55 \pm 0.00^{\mathrm{Bd}}$ \\
& 15 & $0.42 \pm 0.01$ & $0.59 \pm 0.00^{\mathrm{Cd}}$ & $0.56 \pm 0.00^{\mathrm{Bc}}$ & $0.52 \pm 0.00^{\mathrm{Ab}}$ \\
& 21 & $0.34 \pm 0.00$ & $0.51 \pm 0.00^{\mathrm{Ab}}$ & $0.54 \pm 0.00^{\mathrm{Cb}}$ & $0.53 \pm 0.00^{\mathrm{Bc}}$ \\
& 28 & $0.44 \pm 0.01$ & $0.48 \pm 0.00^{\mathrm{Aa}}$ & $0.52 \pm 0.00^{\mathrm{Ca}}$ & $0.51 \pm 0.00^{\mathrm{Ba}}$ \\
& & & & & \\
& 1 & $14.22 \pm 0.15$ & $22.83 \pm 0.26^{\mathrm{Cb}}$ & $21.94 \pm 0.22^{\mathrm{Ba}}$ & $18.39 \pm 0.15^{\mathrm{Aa}}$ \\
& 7 & $11.97 \pm 0.14$ & $21.37 \pm 0.16^{\mathrm{Aa}}$ & $26.91 \pm 0.17^{\mathrm{Cb}}$ & $24.80 \pm 0.26^{\mathrm{Bc}}$ \\
& 15 & $12.28 \pm 0.16$ & $26.94 \pm 0.51^{\mathrm{Bd}}$ & $27.69 \pm 0.60^{\mathrm{Bb}}$ & $23.46 \pm 0.18^{\mathrm{Ab}}$ \\
& 21 & $9.05 \pm 0.01$ & $24.61 \pm 0.17^{\mathrm{Bc}}$ & $27.17 \pm 0.27^{\mathrm{Cb}}$ & $23.46 \pm 0.31^{\mathrm{Ab}}$ \\
& 28 & $14.46 \pm 0.11$ & $32.14 \pm 0.34^{\mathrm{Bb}}$ & $31.60 \pm 0.13^{\mathrm{Bc}}$ & $26.60 \pm 0.28^{\mathrm{Ad}}$ \\
\hline
\end{tabular}

TPA: Texture profile texture $(\mathrm{n}=15)$. MAP samples were previously ozonated and freeze-dried

A,B,C Different capital letters in the same row indicate that means are significantly different $(P<0.05)$ between the different MAP packaging

.a,b,c Different lowercase letters in the same column indicate that means are significantly different $(P<0.05)$ between days of storage

\section{Sensory descriptive analyses}

Results of sensory analyses for appearance, hardness and juiciness are represented in Figure 5.1. The appearance attribute, on high oxygen packaged samples $(30 \% \mathrm{O} 2 / 70$ $\left.\% \mathrm{~N}_{2}\right)$ was less scored $(P<0.05)$ by panelists than the other groups during the first days. Significant differences were no longer observed after day 15 for these three atmospheres-treated samples.

For hardness and juiciness attributes, significant differences were not observed between samples by day 15. TPA hardness showed a small but significant correlation with respect to sensory hardness $(\mathrm{r}=-0.273 ; P<0.05)$ and juiciness $(\mathrm{r}=-0.266 ; P<0.05)$ attributes. 
High oxygen packaged samples $\left(30 \% \mathrm{O}_{2} / 70 \% \mathrm{~N}_{2}\right)$ received better scores (between 5.5 and 6) by panelists than others treated samples (scores below 5) at day 28. These results did not agree with those of Jongberg, Wen, Tørngren, \& Lund (2014), who found that chicken muscle stored in high-oxygen atmosphere packaging scored lower in tenderness compared to breasts stored in non-oxygen atmosphere.
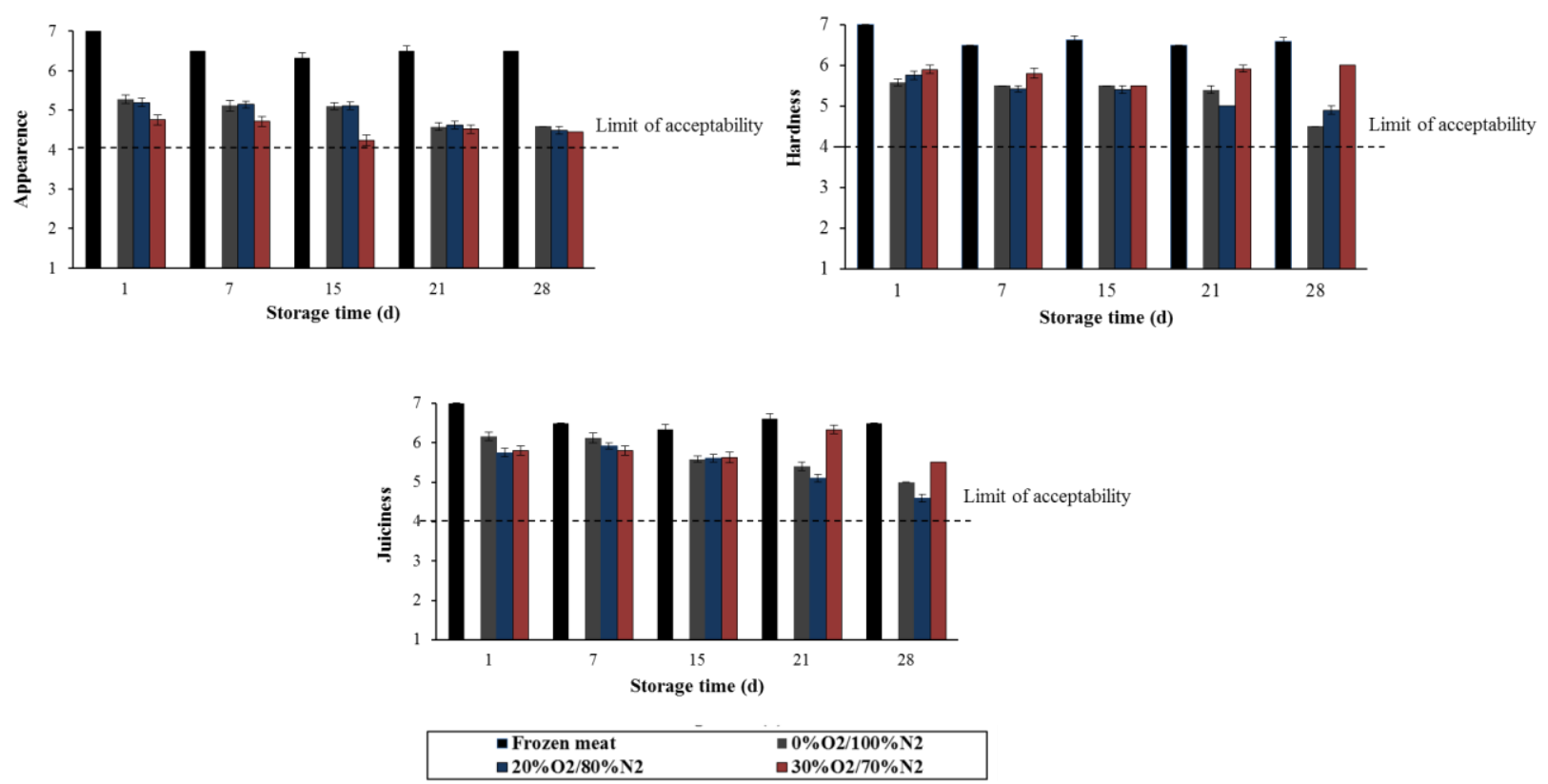

Figure 1. Sensory evaluation of hardness and juiciness on ozonized dried chicken meat stored under different $\mathrm{O}_{2}$ concentration and $0 \% \mathrm{O}_{2} / 100 \% \mathrm{~N}_{2}$ during storage time in days. Means with standard errors $(n=18)$ are shown. Appearance score: $1=$ very different from that of fresh chicken meat, $7=$ very similar to that of fresh meat;

Hardness score: $1=$ very hard, $7=$ very tender; Juiciness score: $1=$ very dry, $7=$ very juicy (4=limit of acceptability).

In general, the scores of all attributes were always above the limit of acceptability (score of 4) in the three types of packages during the storage period. During all storage period, no undesirable odour, flavor or discoloration due to lipid oxidation and nonenzymatic browning were observed by the panelists in the sensory evaluation among all samples. The scores found in our study were higher than those observed by Zouaghi, (2011) using the same scale on chicken samples treated with a combination of ozone, lyophilisation and vacuum-packaging. This suggests that ozonated \& dried chicken meat samples packaged under modified atmospheres maintained desirable sensory characteristics better than those vacuum packaged samples. 
3.2. Trial ii. Packaging with different $\mathrm{CO}_{2}$ concentration (20,30, 40 and $\left.50 \%\right)$

\section{Headspace gas composition}

A decrease in $\mathrm{CO}_{2}$ and an increase in $\mathrm{N}_{2}$ levels were observed in all samples during the storage (data not shown). The $\mathrm{CO}_{2}$ percentage on day 28 showed a significant decrease, the maximum $\mathrm{CO}_{2}$ reduction being in $50 \%$ high- $\mathrm{CO}_{2}$ packages (around $5 \%$ ). Vergara, Berruga, \& Linares (2005) found greater reduction of $\mathrm{CO}_{2}$ levels than those observed in our study. They found around $10 \% \mathrm{CO}_{2}$ reduction on rabbit meat packed with $40 \% \mathrm{CO}_{2} / 60 \% \mathrm{~N}_{2}$ over 20 days of storage. The decrease of $\mathrm{CO}_{2}$ inside the packages could be caused by the absorption of carbon dioxide in meat (Jakobsen \& Bertelsen, 2002).

\section{pH and Color change}

The samples packaged with high $\mathrm{CO}_{2}$ concentrations $\left(50 \% \mathrm{CO}_{2} / 50 \% \mathrm{~N}_{2}\right)$ had significantly lower $\mathrm{pH}$ values than those with lower percentages of $\mathrm{CO}_{2}$ throughout the storage period (Table 5.4). Vergara et al. (2005) also reported lower $\mathrm{pH}$ values in the range of 5.55-5.89 for rabbit meat packaged under high $\mathrm{CO}_{2} \mathrm{MAP}$ conditions during 20 days of storage. Likewise, the $\mathrm{pH}$ values of control and all treated samples slightly decreased during storage, but statistically significant differences $(P<0.05)$ were observed only after 15 days of storage in the case of samples packaged with $30 \% \mathrm{CO}_{2}$ and $40 \% \mathrm{CO}_{2}$. This reduction in the $\mathrm{pH}$ values could be due to the dissolution of $\mathrm{CO}_{2}$ in the product (Lerasle et al., 2014).

Regardless color parameters, lightness $\left(\mathrm{L}^{*}\right)$ values remained more or less stable with storage time for different modified atmosphere packs. The redness values decreased $(P<$ 0.05) with time for all treatments, this decrease being more pronounced for high $\mathrm{CO}_{2}$ MAP (40 and $50 \%$ ) packaged chicken samples than other MAP atmospheres. According to our results, Vergara et al. (2005) also reported color changes of rabbit meat, that are more relevant and happen more quickly with high concentrations of $\mathrm{CO}_{2}$. This decrease in $a^{*}$ values may be associated with the oxidation of myoglobin and formation of metmyoglobin (Fernández-López et al., 2008). Finally, the $b^{*}$ values decreased significantly $(P<0.05)$ in all treatments. By day 28 , the yellowness of meat packed with $50 \% \mathrm{CO}_{2}$ was lower than that in other packaged samples. Significant differences $(P<0.05)$ were observed in $\Delta \mathrm{E}$ values with respect to storage time for different modified atmosphere packs. According to Chouhan et al., (2015), the total color difference $\left(\Delta \mathrm{E}^{*}\right)$ values between 3.0 and 6.0 can be considerate as very distinct 
color difference 6.0 to 12.0 indicates a great visual change and the values higher at 12 for very great difference. According to this scale, there was large color changes in samples packed with 20 and $40 \% \mathrm{CO}_{2}\left(\Delta \mathrm{E}^{*}\right.$ values of 9.8 and 7.8 , respectively), while a very distinct color differences were obtained for samples stored at 30 and $50 \% \mathrm{CO}_{2}$ $\left(\Delta \mathrm{E}^{*}\right.$ values of 5.7 and 5.5 , respectively). 
Table 4. Changes in $\mathrm{pH}, \mathrm{L}^{*}, \mathrm{a}^{*}$ and $\mathrm{b}^{*}$ values of chicken meat stored in different modified atmosphere packs of $\mathrm{CO}_{2}$ at room temperature during 28 days of storage

\begin{tabular}{|c|c|c|c|c|c|c|}
\hline Parameters & Days of storage & Frozen meat (FM) & & MAP & dition & \\
\hline \multirow{6}{*}{$\mathrm{pH}$} & & & $20 \% \mathrm{CO}_{2} / 80 \% \mathrm{~N}_{2}$ & $30 \% \mathrm{CO}_{2} / 70 \% \mathrm{~N}_{2}$ & $40 \% \mathrm{CO}_{2} / 60 \% \mathrm{~N}_{2}$ & $50 \% \mathrm{CO}_{2} / 50 \% \mathrm{~N}_{2}$ \\
\hline & 1 & $6.03 \pm 0.04$ & $6.03 \pm 0.04^{\mathrm{BCa}}$ & $6.15 \pm 0.03^{\mathrm{Cc}}$ & $5.98 \pm 0.03^{\mathrm{Bb}}$ & $5.74 \pm 0.02^{\mathrm{Aa}}$ \\
\hline & 7 & $6.00 \pm 0.01$ & $6.00 \pm 0.03^{\mathrm{BCa}}$ & $6.12 \pm 0.04^{\mathrm{Cbc}}$ & $5.91 \pm 0.04^{\mathrm{Bab}}$ & $5.73 \pm 0.04^{\mathrm{Aa}}$ \\
\hline & 15 & $6.05 \pm 0.03$ & $5.97 \pm 0.03^{\mathrm{Ba}}$ & $6.01 \pm 0.03^{\mathrm{Bab}}$ & $5.88 \pm 0.02^{\mathrm{Ba}}$ & $5.71 \pm 0.04^{\mathrm{Aa}}$ \\
\hline & 21 & $5.99 \pm 0.02$ & $5.95 \pm 0.06^{\mathrm{Ba}}$ & $5.99 \pm 0.03^{\mathrm{Bab}}$ & $5.87 \pm 0.04^{\mathrm{Ba}}$ & $5.70 \pm 0.02^{\mathrm{Aa}}$ \\
\hline & 28 & $5.98 \pm 0.03$ & $5.86 \pm 0.03^{\mathrm{BCa}}$ & $5.93 \pm 0.02^{\mathrm{Ca}}$ & $5.79 \pm 0.02^{\mathrm{Ba}}$ & $5.68 \pm 0.03^{\mathrm{Aa}}$ \\
\hline \multirow[t]{5}{*}{$\mathrm{L}^{*}$} & 1 & $45.73 \pm 0.18$ & $71.68 \pm 0.45^{\mathrm{Bc}}$ & $66.33 \pm 0.73^{\mathrm{Aab}}$ & $65.15 \pm 0.24^{\mathrm{Aa}}$ & $64.93 \pm 0.91^{\mathrm{Aab}}$ \\
\hline & 7 & $42.39 \pm 0.88$ & $63.17 \pm 0.70^{\mathrm{Aab}}$ & $67.14 \pm 0.74^{\mathrm{Bab}}$ & $64.41 \pm 0.57^{\mathrm{ABa}}$ & $65.05 \pm 1.00^{\mathrm{ABab}}$ \\
\hline & 15 & $48.84 \pm 0.73$ & $65.55 \pm 0.63^{\mathrm{Ab}}$ & $67.43 \pm 0.88^{\mathrm{Ab}}$ & $65.06 \pm 0.71^{\mathrm{Aa}}$ & $65.06 \pm 0.66^{\mathrm{Aab}}$ \\
\hline & 21 & $47.30 \pm 0.58$ & $64.06 \pm 0.87^{\mathrm{Aab}}$ & $63.97 \pm 0.82^{\mathrm{Aa}}$ & $64.89 \pm 0.68^{\mathrm{ABa}}$ & $67.39 \pm 0.67^{\mathrm{Bb}}$ \\
\hline & 28 & $42.11 \pm 0.46$ & $62.53 \pm 0.55^{\mathrm{Aa}}$ & $64.66 \pm 0.54^{\mathrm{Aab}}$ & $71.81 \pm 0.64^{\mathrm{Ab}}$ & $63.03 \pm 0.89^{\mathrm{Aa}}$ \\
\hline \multirow[t]{5}{*}{$a^{*}$} & 1 & $1.03 \pm 0.01$ & $2.66 \pm 0.03^{\mathrm{Ae}}$ & $2.66 \pm 0.02^{\mathrm{Bd}}$ & $3.48 \pm 0.02^{\mathrm{Bd}}$ & $3.46 \pm 0.01^{\mathrm{Ae}}$ \\
\hline & 7 & $1.01 \pm 0.01$ & $2.56 \pm 0.01^{\mathrm{Cd}}$ & $2.25 \pm 0.01^{\mathrm{Ac}}$ & $2.57 \pm 0.02^{\mathrm{Cc}}$ & $2.35 \pm 0.01^{\mathrm{Bd}}$ \\
\hline & 15 & $1.15 \pm 0.04$ & $2.28 \pm 0.02^{\mathrm{Bc}}$ & $2.29 \pm 0.01^{\mathrm{Bc}}$ & $2.31 \pm 0.02^{\mathrm{Bb}}$ & $2.06 \pm 0.01^{\mathrm{Ac}}$ \\
\hline & 21 & $1.27 \pm 0.01$ & $1.84 \pm 0.02^{\mathrm{Bb}}$ & $2.10 \pm 0.03^{\mathrm{Cb}}$ & $1.62 \pm 0.02^{\mathrm{Ab}}$ & $1.90 \pm 0.01^{\mathrm{Bb}}$ \\
\hline & 28 & $0.97 \pm 0.01$ & $1.66 \pm 0.01^{\mathrm{Ba}}$ & $1.55 \pm 0.01^{\mathrm{Aa}}$ & $1.55 \pm 0.02^{\mathrm{Aa}}$ & $1.60 \pm 0.02^{\mathrm{ABa}}$ \\
\hline \multirow[t]{5}{*}{$b^{*}$} & 1 & $10.36 \pm 0.40$ & $17.20 \pm 0.17^{\mathrm{Ac}}$ & $19.94 \pm 0.24^{\mathrm{Cc}}$ & $18.98 \pm 0.25^{\mathrm{Bd}}$ & $18.76 \pm 0.12^{\mathrm{Bc}}$ \\
\hline & 7 & $10.12 \pm 0.13$ & $14.28 \pm 0.18^{\mathrm{Aa}}$ & $14.00 \pm 0.10^{\mathrm{Aa}}$ & $16.13 \pm 0.23^{\mathrm{Bc}}$ & $17.95 \pm 0.21^{\mathrm{Cb}}$ \\
\hline & 15 & $7.26 \pm 0.08$ & $17.41 \pm 0.20^{\mathrm{Ac}}$ & $19.57 \pm 0.15^{\mathrm{Cc}}$ & $18.69 \pm 0.16^{\mathrm{BCd}}$ & $18.52 \pm 0.15^{\mathrm{Bbc}}$ \\
\hline & 21 & $7.36 \pm 0.06$ & $15.91 \pm 0.16^{\mathrm{Cb}}$ & $15.27 \pm 0.13^{\mathrm{Bb}}$ & $12.95 \pm 0.14^{\mathrm{Aa}}$ & $13.41 \pm 0.11^{\mathrm{Aa}}$ \\
\hline & 28 & $9.95 \pm 0.05$ & $13.98 \pm 0.16^{\mathrm{Aa}}$ & $14.60 \pm 0.19^{\mathrm{Bab}}$ & $15.39 \pm 0.10^{\mathrm{Cb}}$ & $13.91 \pm 0.16^{\mathrm{Aa}}$ \\
\hline
\end{tabular}

Data are expressed as means \pm standard error $(\mathrm{n}=10)$. MAP samples were previously ozonated and freeze-dried.

$\mathrm{A}, \mathrm{B}, \mathrm{C}$ Different capital letters in the same row indicate that means are significantly different $(P<0.05)$ between the different MAP packaging:

a,b,c Different lowercase letters in the same column indicate that means are significantly different $(P<0.05)$ between days of storage 


\section{Texture analyses}

Results for texture profile analyses of control (untreated) and treated chicken meat stored in different modified atmosphere packs of $\mathrm{CO}_{2}$ are presented in Table 5.5. Both MAP conditions and storage time had significant effects on meat texture parameters. Hardness, cohesiveness and chewiness values of all treated samples meat decreased significantly from day 7 onwards, such decreases being greater in the samples packaged with $20 \% \mathrm{CO}_{2}$ than with others atmospheres. According to these results, the MAP with $20 \% \mathrm{CO}_{2} / 80 \% \mathrm{~N}_{2}$ could be sufficient for preserving the initial textural properties of the ozonated dried chicken meat similar to those of raw meat for a period of 28 days.

Table 5. Effects of carbon dioxide level on texture parameters of chicken meat stored in different modified atmosphere packs

\begin{tabular}{|c|c|c|c|c|c|c|}
\hline \multirow[t]{2}{*}{ Parameters } & \multirow{2}{*}{$\begin{array}{l}\text { Days of } \\
\text { storage }\end{array}$} & \multirow{3}{*}{$\begin{array}{c}\text { Frozen meat } \\
(\mathrm{FM})\end{array}$} & \multicolumn{4}{|c|}{ MAP condition } \\
\hline & & & $20 \% \mathrm{CO}_{2} / 80 \% \mathrm{~N}_{2}$ & $30 \% \mathrm{CO}_{2} / 70 \% \mathrm{~N}_{2}$ & $40 \% \mathrm{CO}_{2} / 60 \% \mathrm{~N}_{2}$ & $50 \% \mathrm{CO}_{2} / 50 \% \mathrm{~N}_{2}$ \\
\hline \multicolumn{6}{|l|}{ Hardness (N) } & \\
\hline & 1 & $34.32 \pm 0.44$ & $65.12 \pm 0.65^{\mathrm{Cc}}$ & $68.27 \pm 0.20^{\mathrm{Dc}}$ & $61.81 \pm 0.60^{\mathrm{Bc}}$ & $59.17 \pm 0.50^{\mathrm{Ab}}$ \\
\hline & 7 & $33.44 \pm 0.35$ & $64.46 \pm 0.49^{\mathrm{Bc}}$ & $52.90 \pm 0.45^{\mathrm{Ab}}$ & $52.20 \pm 0.56^{\mathrm{Aab}}$ & $50.85 \pm 0.44^{\mathrm{Aa}}$ \\
\hline & 15 & $31.60 \pm 0.25$ & $55.27 \pm 0.22^{\mathrm{Bc}}$ & $53.66 \pm 0.34^{\mathrm{Bb}}$ & $55.13 \pm 0.45^{\mathrm{Bc}}$ & $49.43 \pm 0.30^{\mathrm{Aa}}$ \\
\hline & 21 & $30.78 \pm 0.34$ & $54.04 \pm 0.55^{\mathrm{Bb}}$ & $52.94 \pm 0.33^{\mathrm{Bb}}$ & $54.28 \pm 0.50^{\mathrm{Bb}}$ & $49.02 \pm 0.47^{\mathrm{Aa}}$ \\
\hline & 28 & $35.80 \pm 0.09$ & $40.98 \pm 0.49^{\mathrm{Aa}}$ & $50.52 \pm 0.65^{\mathrm{Cc}}$ & $50.24 \pm 0.40^{\mathrm{Cc}}$ & $47.99 \pm 0.34^{\mathrm{Bb}}$ \\
\hline \multicolumn{7}{|l|}{ Cohesiveness } \\
\hline & 1 & $0.42 \pm 0.00$ & $0.58 \pm 0.00^{\mathrm{Cd}}$ & $0.56 \pm 0.00^{\mathrm{Ad}}$ & $0.57 \pm 0.00^{\mathrm{Be}}$ & $0.59 \pm 0.00^{\mathrm{De}}$ \\
\hline & 7 & $0.41 \pm 0.01$ & $0.56 \pm 0.00^{\mathrm{Cc}}$ & $0.56 \pm 0.00^{\mathrm{Cd}}$ & $0.54 \pm 0.00^{\mathrm{Ac}}$ & $0.55 \pm 0.00^{\mathrm{Bb}}$ \\
\hline & 15 & $0.43 \pm 0.01$ & $0.56 \pm 0.00^{\mathrm{Cc}}$ & $0.55 \pm 0.00^{\mathrm{Ac}}$ & $0.56 \pm 0.00^{\mathrm{Bd}}$ & $0.54 \pm 0.00^{\mathrm{Ab}}$ \\
\hline & 21 & $0.34 \pm 0.00$ & $0.50 \pm 0.00^{\mathrm{Ab}}$ & $0.52 \pm 0.00^{\mathrm{Bb}}$ & $0.53 \pm 0.00^{\mathrm{Cb}}$ & $0.54 \pm 0.00^{\mathrm{Db}}$ \\
\hline & 28 & $0.41 \pm 0.01$ & $0.44 \pm 0.00^{\mathrm{Aa}}$ & $0.48 \pm 0.00^{\mathrm{Ba}}$ & $0.52 \pm 0.00^{\mathrm{Ca}}$ & $0.53 \pm 0.00^{\mathrm{Ca}}$ \\
\hline \multirow{6}{*}{$\begin{array}{l}\text { Chewiness } \\
(\mathrm{N} / \mathrm{mm})\end{array}$} & & & & & & \\
\hline & 1 & $14.22 \pm 0.15$ & $36.12 \pm 0.11^{\mathrm{Ce}}$ & $37.11 \pm 0.39^{\mathrm{Dd}}$ & $29.76 \pm 0.17^{\mathrm{Ac}}$ & $30.80 \pm 0.09^{\mathrm{Bc}}$ \\
\hline & 7 & $11.97 \pm 0.14$ & $30.32 \pm 0.24^{\mathrm{Cd}}$ & $23.78 \pm 0.14^{\mathrm{Aa}}$ & $27.07 \pm 0.26^{\mathrm{Bc}}$ & $24.86 \pm 0.22^{\mathrm{Ab}}$ \\
\hline & 15 & $12.28 \pm 0.16$ & $31.70 \pm 0.37^{\mathrm{Cd}}$ & $26.76 \pm 0.29^{\mathrm{Bb}}$ & $29.04 \pm 0.30^{\mathrm{Cc}}$ & $24.94 \pm 0.22^{\mathrm{Aa}}$ \\
\hline & 21 & $9.05 \pm 0.01$ & $28.28 \pm 0.30^{\mathrm{Bc}}$ & $26.67 \pm 0.33^{\mathrm{Ab}}$ & $28.54 \pm 0.09^{\mathrm{Bc}}$ & $25.16 \pm 0.19^{\mathrm{Aa}}$ \\
\hline & 28 & $14.46 \pm 0.11$ & $18.25 \pm 0.17^{\mathrm{Aa}}$ & $28.08 \pm 0.30^{\mathrm{Cd}}$ & $26.65 \pm 0.22^{\mathrm{Cc}}$ & $23.40 \pm 0.21^{\mathrm{Bb}}$ \\
\hline
\end{tabular}

\section{Sensory descriptive analysis}

In terms of the overall acceptability descriptor (Figure 5.2), panelists preferred $(P<$ 0.05) the control samples than the treated samples throughout the whole storage period. In general, chicken breast fillets packed with $50 \% \mathrm{CO}_{2} / 50 \% \mathrm{~N}_{2}$ were also less acceptable in the last days of storage (days 21 and 28) by panelists than the other MAP packaged samples $\left(20,30\right.$ and $\left.40 \% \mathrm{CO}_{2}\right)$. 
Regarding hardness and juiciness attributes, both time of storage and the type of packaging significantly affected them. In agreement with texture data, the same samples that showed low values in hardness and chewiness corresponded to those that received better scores by the panel. TPA Hardness had significant correlations with respect to sensory perceived hardness and juiciness with correlation coefficients higher than 0.5 (hardness $\mathrm{r}=-0.638$; chewiness $\mathrm{r}=-0.540, P<0.05$ ). Chewiness produced significant correlations with panel juiciness $(\mathrm{r}=-0.540 ; P<0.05)$ and hardness $(\mathrm{r}=-0.610 ; P<0.05)$. Significant correlations were also observed between cohesiveness and sensory hardness ( $\mathrm{r}=-0.526 ; P<0.05)$. González-Fernández, Santos, Rovira, and Jaime (2006) found interrelationship between sensorial and instrumental hardness and chewiness in other meat products.
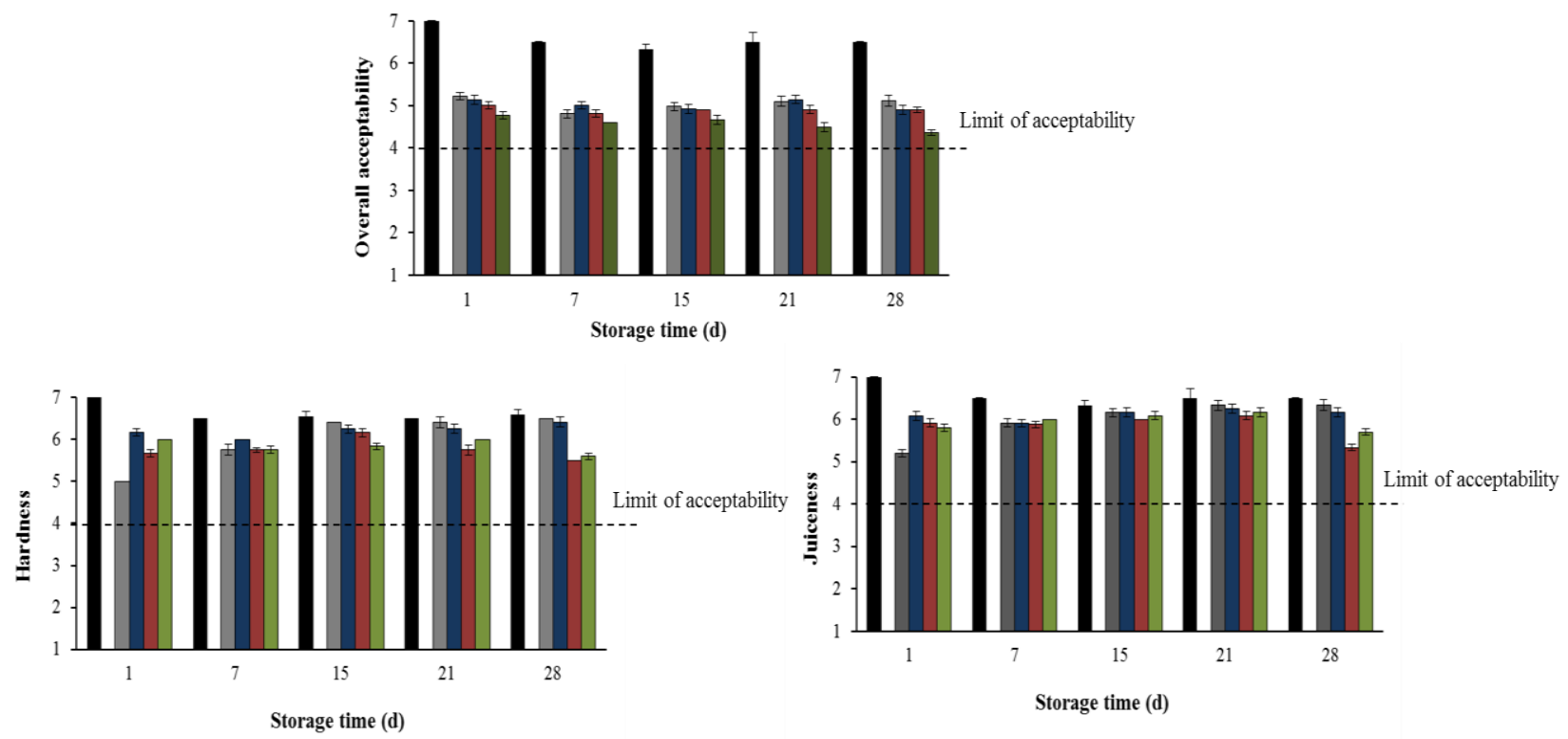

Figure 2. Sensory descriptive analyses on ozonated dried chicken meat for MAP experiments with different $\mathrm{CO}_{2}$ concentration. Means with standard errors $(\mathrm{n}=18)$ are shown. Overall acceptability: $1=$ Reject (very different from fresh chicken meat), $7=$ acceptable (very similar to fresh chicken meat); Hardness score: 1=very hard, $7=$ very tender; Juiciness score: $1=$ very dry, $7=$ very juicy (4=limit of acceptability). 
The samples packed with 20 and $30 \% \mathrm{CO}_{2}$ were perceived by panelists as significantly $(P<0.05)$ more tender and juicier than the other treated samples. Interestingly, under the $20 \% \mathrm{CO}_{2} / 80 \% \mathrm{~N}_{2}$ packaging condition, samples received scores in hardness and juiciness similar to those of control samples (raw meat) from day 15 onwards, as the panelists did not find significant differences between the samples. Based on these results, the $20 \% \mathrm{CO}_{2} / 80 \% \mathrm{~N}_{2}$ treatment was considered to be the most effective one in maintaining the sensory quality of chicken breast fillets treated with ozone and freeze-drying during 28 days of storage.

\subsection{Trial iii. MAP gas mixtures with different concentrations of $\mathrm{CO}_{2}$ and $\mathrm{O}_{2}$}

\section{Headspace gas composition, $\mathrm{pH}$ and color change}

The headspace atmosphere showed significant changes in composition throughout storage time (data not shown). $\mathrm{O}_{2}$ and $\mathrm{CO}_{2}$ concentrations decreased in all samples, while $\mathrm{N}_{2}$ concentrations increased $(P<0.05)$ during the storage. The greatest changes within packs were observed in those containing low oxygen levels $\left(10 \% \mathrm{O}_{2} / 30 \% \mathrm{CO}_{2} /\right.$ $60 \% \mathrm{~N}_{2}$ ). Similar results were reported by Esmer et al. (2011), who stated relative variations in gaseous atmospheres composition within the modified atmosphere packs, in which the fluctuations were higher at a lower oxygen level.

After day 15, a slight increase in $\mathrm{pH}$ was observed in the samples packed under high $\mathrm{O}_{2}$ MAP conditions $\left(40 \% \mathrm{O}_{2} / 20 \% \mathrm{CO}_{2} / 40 \% \mathrm{~N}_{2}\right)$ from initial $\mathrm{pH}$ of $5.77 \pm 0.01$ to $6.30 \pm$ 0.02 , while it continued decreasing until day 28 in the case of other package treatments (data not shown). The lowest values of $\mathrm{pH}$ were obtained for both MAP $\left(10 \% \mathrm{O}_{2} / 30\right.$ $\% \mathrm{CO}_{2} / 60 \% \mathrm{~N}_{2}$ and $20 \% \mathrm{O}_{2} / 30 \% \mathrm{CO}_{2} / 50 \% \mathrm{~N}_{2}$ ) samples, whose $\mathrm{pH}$ values were below 5.6 at day 28 of storage for both samples.

In relation to color parameters, the type of packaging and storage time had no significant effects on lightness parameter, while minor variations were observed in $a^{*}$ and $b^{*}$ values of chicken meat stored in a gas mixture without $\mathrm{CO}_{2}$ and $\mathrm{O}_{2}$. Redness values for all MAP packaged samples decreased $(P<0.05)$ during storage. This reduction was higher $(P<0.05)$ for high $\mathrm{O}_{2}$ MAP $\left(40 \% \mathrm{O}_{2} / 20 \% \mathrm{CO}_{2} / 40 \% \mathrm{~N}_{2}\right)$ packaged chicken samples by day 28 . The decrease in a* values of meat packaged in high- $\mathrm{O}_{2}$ and low- $\mathrm{CO}_{2}$ atmospheres in this study may be caused by myoglobin oxidation due to high meat's pH observed $(6.30 \pm 0.02$ on day 28$)$ in the same samples. Seydim et al. (2006) stated that at higher $\mathrm{pH}$ values (more than 6 units), the oxidation of 
oxymyoglobin is important, because mitochondrial enzyme systems do not shut down and have the ability to utilize available oxygen.

\section{Texture analyses}

Results of the instrumental texture profile analyses of untreated meat (frozen meat) and samples packed in different gas mixture without $\mathrm{CO}_{2}$ and $\mathrm{O}_{2}$ are shown in Figure 5.3. As can be seen, textural parameters were affected $(P<0.05)$ by the packaging conditions and storage time. Both hardness and chewiness increased significantly throughout storage time in most of packed samples. The increase of these parameters was particularly evident in samples packaged with $40 \% \mathrm{O}_{2} / 20 \% \mathrm{CO}_{2} / 40 \% \mathrm{~N}_{2}$, becoming harder and less chewy meat on day 28. Samples packed with $30 \% \mathrm{O}_{2} / 30$ $\% \mathrm{CO}_{2} / 40 \% \mathrm{~N}_{2}$ showed the lowest values of all textural parameters compared with the rest of packaged samples $(P<0.05)$ on day 28 .
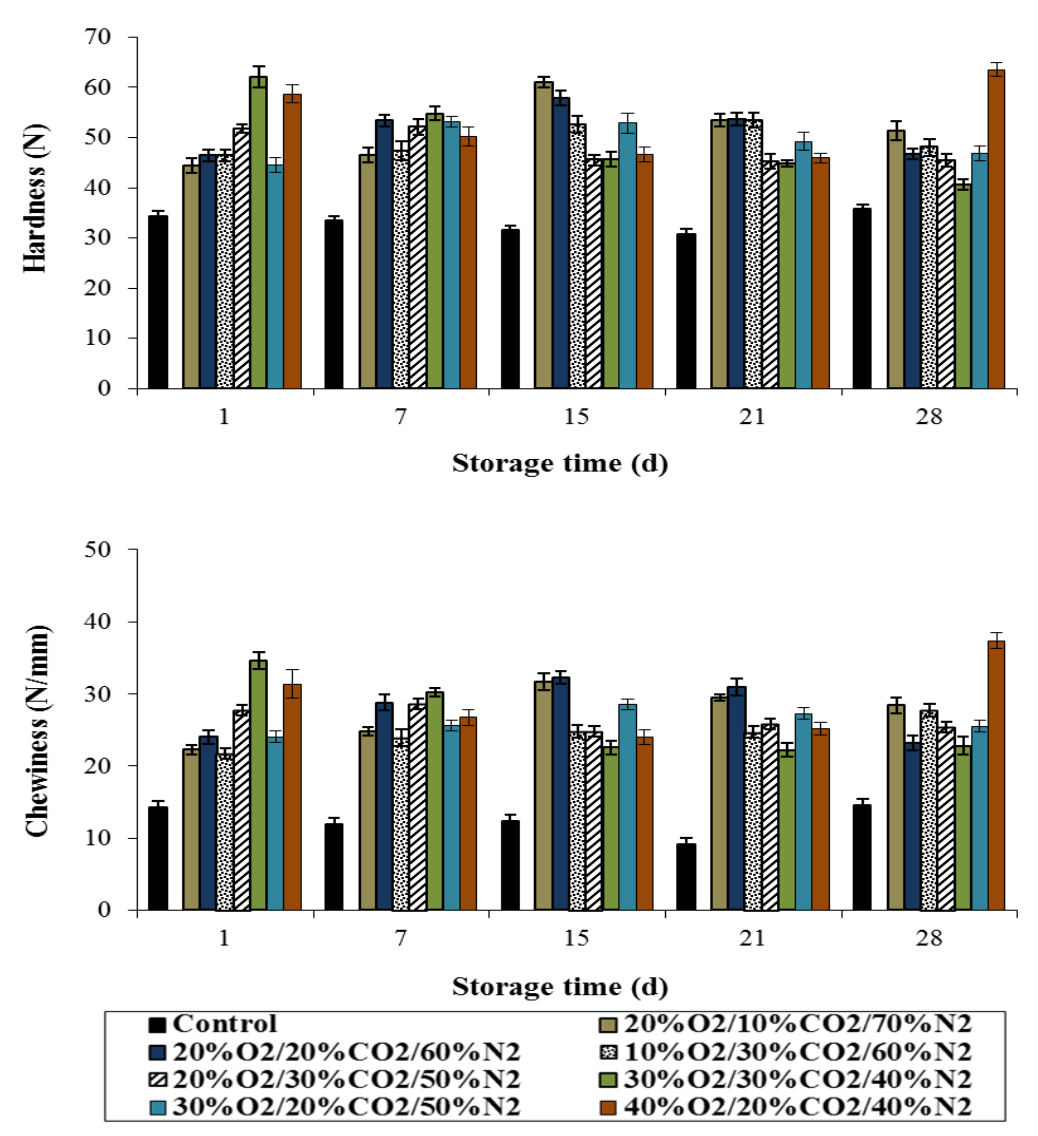

Figure 3. Changes in texture parameters (hardness and chewiness) for control (frozen meat) and samples meat packaged under different various gas mixtures of $\mathrm{O}_{2}: \mathrm{CO}_{2}: \mathrm{N}_{2}$ during storage time (in days). Means with standard errors $(n=15)$ are shown 


\section{Sensory descriptive analyses}

The sensory results were in agreement with instrumental measurements of texture. The instrumental and sensory parameters of hardness showed a significant correlation of $(\mathrm{r}=-0.602, P<0.05)$. TPA chewiness also was significantly correlated $(P<0.01)$ to hardness and chewiness sensory parameters with $\mathrm{r}=-0.724$ and -0.761 , respectively. Results from sensory analyses showed that meat samples packaged with high $\mathrm{O}_{2}$ concentrations $\left(40 \% \mathrm{O}_{2} / 20 \% \mathrm{CO}_{2} / 40 \% \mathrm{~N}_{2}\right)$ scored lower for hardness and juiciness attributes than meat from the others treatments (Figure 5.4). These samples were perceived as harder, less juicy and chewy by panelists, the same samples having showed the highest hardness, cohesiveness and chewiness values in the TPA analyses. These results are in agreement with those of Zakrys-Waliwander, O'Sullivan, Walsh, Allen, and Kerry (2011), who reported that beef steaks stored under high oxygen atmospheres were significantly perceived as less juicy by consumers. The sensory attributes hardness and chewiness did not show significant differences during the storage period, whereas juiciness decreased $(P<0.05)$ in all samples.
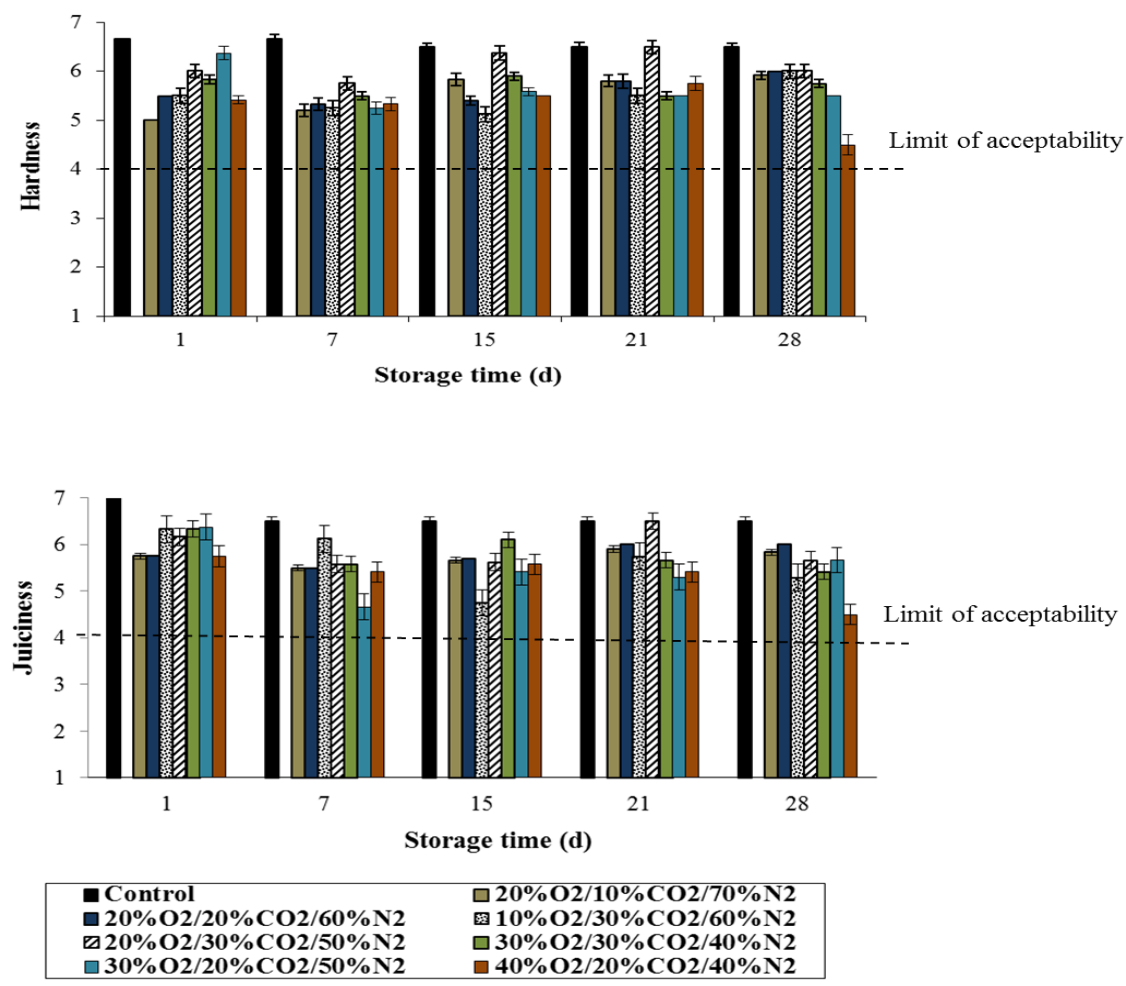

Figure 4. Sensory descriptive analyses on ozonated dried chicken meat for MAP experiments with different $\mathrm{CO}_{2}$ concentration. Means with standard errors $(n=18)$ are shown. Hardness score: $1=$ very hard, $7=$ very tender; Juiciness score: $1=$ very dry, $7=$ very juicy (4=limit of acceptability). 
At 28 days of storage, all samples received high scores between 4.5 and 6 for juiciness, indicating "juicy" and "very juicy" meat according to the scale used. Zouaghi (2011) found an important decrease in juiciness for ozonated dried chicken meat stored in vacuum packed and reported lower juiciness compared to our study. To sum up, modified atmosphere packaging preserved juiciness of samples more efficiently than vacuum packaging.

\section{Conclusions}

Increasing the concentrations of oxygen (more than $30 \%$ with or without $\mathrm{CO}_{2}$ ) in modified atmosphere gas compositions resulted in loss of redness and an increase in the $\mathrm{pH}$ values. Also, when the concentration of $\mathrm{CO}_{2}$ in modified atmosphere was more than $40 \%$, a decrease of the $a^{*}$ and $b^{*}$ values of treated samples happened. However, the texture and sensory properties of ozonated dried chicken meat packaged in modified atmospheres were best preserved in atmospheres containing low $\mathrm{CO}_{2}$ concentrations (20-30\%) rather than high (40-50\%) concentrations.

As a result, the best preservation conditions for ozonated dried chicken breast fillets stored at room temperature was in MAP $\left(20 \% \mathrm{CO}_{2} / 80 \% \mathrm{~N}_{2}\right)$ gas combination, maintaining acceptable color together with texture and sensory quality (hardness and juiciness attributes were scored above the limit of acceptability, and also being more similar to the characteristics of raw meat during 28 days of storage). A long-term study is being carried out to determine the self-life of the new product under those optimal conditions.

\section{References}

Babić, J., Cantalejo, M. J., \& Arroqui, C. (2009). The effects of freeze-drying process parameters on Broiler chicken breast meat. LWT - Food Science and Technology, 42(8), 1325-1334.

Bourne, M. C. (1978). Texture profile analysis. Food Technology, 32(7), 62- 72.

Cantalejo, M. J., Zouaghi, F., \& Pérez-Arnedo, I. (2016). Combined effects of ozone and freeze-drying on the shelf-life of Broiler chicken meat. LWT - Food Science and Technology, 68, 400-407. 
Chouhan, A., Pal, B., \& Rao, P. S. (2015). Effect of high pressure processing and thermal treatment on quality of hilsa ( Tenualosa ilisha ) fi llets during refrigerated storage. Innovative Food Science and Emerging Technologies, 29, 151-160.

Chouliara, E., Karatapanis, A., Savvaidis, I. N., \& Kontominas, M. G. (2007). Combined effect of oregano essential oil and modified atmosphere packaging on shelf-life extension of fresh chicken breast meat, stored at $4{ }^{\circ} \mathrm{C}$. Food Microbiology, 24(6), 607-617.

Esmer, O. K., Irkin, R., Degirmencioglu, N., \& Degirmencioglu, A. (2011). The effects of modified atmosphere gas composition on microbiological criteria, color and oxidation values of minced beef meat. Meat Science, 88(2), 221-226.

Fernández-López, J., Sayas-Barberá, E., Muñoz, T., Sendra, E., Navarro, C., \& PérezAlvarez, J. A. (2008). Effect of packaging conditions on shelf-life of ostrich steaks. Meat Science, 78(1-2), 143-152.

Ganhão, R., Morcuende, D., \& Estévez, M. (2010). Protein oxidation in emulsified cooked burger patties with added fruit extracts: Influence on colour and texture deterioration during chill storage. Meat Science, 85(3), 402-409.

García-Esteban, M., Ansorena, D., \& Astiasarán, I. (2004). Comparison of modified atmosphere packaging and vacuum packaging for long period storage of dry-cured ham : effects on colour, texture and microbiological quality. Meat Science, 67, 5763.

González-Fernández, C., Santos, E. M., Rovira, J., \& Jaime, I. (2006). The effect of sugar concentration and starter culture on instrumental and sensory textural properties of chorizo-Spanish dry-cured sausage. Meat Science, 74(3), 467-475.

Hunt, M.C., Acton, J.C., Benedict, R.C., Calkins, C.R., Cornforth D.P., Jeremiah, L.E., Olson, D.G., Salm, C.P., Savell, J.W., \& Shivas, S.D. (1991). AMSA guidelines for meat color evaluation. In Proceedings $44^{\text {th }}$ Annual Reciprocal Meat Conference (pp. 3-17), 9-12 July 1991, Kansas State University, Manhattan, KS.

Jakobsen, M., \& Bertelsen, G. (2002). The use of CO2 in package of fresh red meats and its effect on chemical quality changes in the meat: a review. Journal of Muscle Foods, 13(2002), 143-168.

Jongberg, S., Wen, J., Tørngren, M. A., \& Lund, M. N. (2014). Effect of high-oxygen atmosphere packaging on oxidative stability and sensory quality of two chicken muscles during chill storage. Food Packaging and Shelf Life, 1(1), 38-48. 
Keokamnerd, T., Acton, J. C., Han, I. Y., \& Dawson, P. L. (2008). Effect of commercial rosemary oleoresin preparations on ground chicken thigh meat quality packaged in a high-oxygen atmosphere. Poultry Science, 87(1), 170-179.

Kim, J., Yousef, A. E., \& Chism, G. W. (1999). Use of ozone to inactivate microorganisms on lattuce. Journal of Food Safety, 19(1), 17-34.

Lerasle, M., Federighi, M., Simonin, H., Anthoine, V., Rezé, S., Chéret, R., \& Guillou, S. (2014). Combined use of modified atmosphere packaging and high pressure to extend the shelf-life of raw poultry sausage. Innovative Food Science and Emerging Technologies, 23, 54-60.

Lyon, B. G., \& Lyon, C. E. (1990). Texture Profile of Broiler Pectoralis major as Influenced by Post-Mortem Deboning Time and Heat Method. Poultry Science, 69(2), 329-340.

Meral, Y., \& Mahmut, S. (2016). Effect of salt and moisture content reduction on physical and microbiological properties of salted, pressed and freeze dried turkey meat. LWT - Food Science and Technology, 68, 153-159.

Nair, D. V. T., Kiess, A., Nannapaneni, R., Schilling, W., \& Sharma, C. S. (2015). The combined efficacy of carvacrol and modified atmosphere packaging on the survival of Salmonella, Campylobacter jejuni and lactic acid bacteria on Turkey breast cutlets. Food Microbiology, 49, 134-141.

Narasimha Rao, D., \& Sachindra, N. M. (2002). Modified Atmosphere and Vacuum Packaging of Meat and Poultry Products. Food Reviews International, 18(4), 263293.

Petrou, S., Tsiraki, M., Giatrakou, V., \& Savvaidis, I. N. (2012). Chitosan dipping or oregano oil treatments, singly or combined on modified atmosphere packaged chicken breast meat. International Journal of Food Microbiology, 156(3), 264271.

Rossaint, S., Klausmann, S., \& Kreyenschmidt, J. (2015). Effect of high-oxygen and oxygen-free modified atmosphere packaging on the spoilage process of poultry breast fillets. Poultry Science, 94, 96-103.

Savadkoohi, S., Hoogenkamp, H., Shamsi, K., \& Farahnaky, A. (2014). Color , sensory and textural attributes of beef frankfurter, beef ham and meat-free sausage containing tomato pomace. MESC, 97(4), 410-418.

Seydim, a. C., Acton, J. C., Hall, M. a., \& Dawson, P. L. (2006). Effects of packaging atmospheres on shelf-life quality of ground ostrich meat. Meat Science, 73(3), 503-510. 
Szczesniak, A. S. (2002). Texture is a sensory property. Food Quality and Preference, $13,215-225$.

Vergara, H., Berruga, M. I., \& Linares, M. B. (2005). Effect of gas composition on rabbit meat quality in modified atmosphere packaging. Journal of the Science of Food and Agriculture, 85(12), 1981-1986.

Zakrys-Waliwander, P. I., O’Sullivan, M. G., Walsh, H., Allen, P., \& Kerry, J. P. (2011). Sensory comparison of commercial low and high oxygen modified atmosphere packed sirloin beef steaks. Meat Science, 88(1), 198-202.

Zouaghi, F. (2011). Study of the effect of ozone on quality and shelf-life of freeze- dried Broiler chicken breasts. Ms Thesis. Public University of Navarra. Pamplona. Spain. 